\title{
SPACIAL INDEXES AND BIOLOGICAL DIVERSITY OF ITANHAÉM, SÃO PAULO, BRAZIL
}

\author{
Tamara Ribeiro Botelho de Carvalho Maria ${ }^{1}{ }^{*}$, Daniela Biondi ${ }^{2}$, Kendra Zamproni $^{3}$ \\ 1 *Federal University of Paraná, Department of Forestry Sciences, Curitiba, Paraná, Brazil - trbotelhomaria@gmail.com (*) \\ ${ }^{2}$ Federal University of Paraná, Department of Forestry Sciences, Curitiba, Paraná, Brazil - dbiondi@ ufpr.br \\ ${ }^{3}$ Federal University of Paraná, Department of Forestry Sciences, Curitiba, Paraná, Brazil - kendra.zam@ gmail.com
}

Received for publication: 16/01/2018 - Accepted for publication:25/07/2018

\begin{abstract}
Many managers have studied the afforestation as a mitigating tool for the problems caused by urbanization, since the specific knowledge of each municipality is fundamental for proper planning in relation to the species used, the number of trees and the location in the municipality. The present research had the objective of evaluating the spatial and biological diversity indexes of the road arborization of the city of Itanhaém - SP. For the accomplishment of the research, a qualitative and quantitative inventory of the arborization was done to obtain the coverage indices and tree density, index of full occupation, current occupation and the deficit of afforestation and the performance index of the species. There is 1 tree for each $100 \mathrm{~m}^{2}$ of sidewalk in the municipality, $2.35 \%$ of the sidewalks are covered by the crown of the trees and the municipality presents only $21.1 \%$ of the ideal afforestation. The municipality had a high diversity index of Shannon $\mathrm{H}^{\prime}=3.45$ and Simpson dominance $\lambda=0.082$. The native species with the best performance index was Schinus terebinthifolius. Although there are species diversity in the municipality, the current situation demonstrates the scarcity of trees, indicating the need for intensification in the planting of trees in the road system.

Keywords: afforestation planning, urban forest, ecological indexes.
\end{abstract}

\section{Resumo}

Índices espaciais e de diversidade biológica da arborização viária de itanhaém - SP Muitos gestores têm estudado a arborização como ferramenta mitigatória dos problemas causados pela urbanização, já que o conhecimento específico de cada município é fundamental para o planejamento adequado em relação as espécies utilizadas, a quantidade de árvores e a localização no município. A presente pesquisa teve por objetivo avaliar os índices espaciais e de diversidade biológica da arborização viária do município de Itanhaém - SP. Para realização da pesquisa, foi feito um inventário amostral, quali-quantitativo da arborização para obtenção dos índices de cobertura e densidade arbórea, índice de plena ocupação, de ocupação atual e o déficit da arborização e o índice de performance da espécie. Existe no município 1 árvore para cada $100 \mathrm{~m}^{2}$ de calçada, 2,35\% das calçadas são cobertas pela projeção da copa das árvores e o município apresenta apenas 21,1\% da arborização ideal. Existe no município 1 árvore para cada $100 \mathrm{~m}^{2}$ de calçada, 2,35\% das calçadas são cobertas pela projeção da copa das árvores e o município apresenta apenas $21,1 \%$ da arborização ideal. A espécie nativa com melhor índice de performance foi Schinus terebinthifolius. Embora exista diversidade de espécies no município, a atual situação demonstra a escassez de árvores, indicando a necessidade de intensificação no plantio de árvores no sistema viário.

Palavras-chave: planejamento da arborização, floresta urbana, índices ecológicos.

\section{INTRODUCTION}

In the midst of the expansion of the urban territory, the vegetation is losing space and being replaced by constructions and elements of urbanization necessary to the routine of the population. This reality can be observed in numerous Brazilian municipalities, among them the municipality of Itanhaém, where this process occurs since 1532 and that, despite having a significant extension of preserved Atlantic Forest, the urban population still exerts great influence under the decrease of vegetated areas.

The loss of vegetation in the daily life of the population has a direct influence on their quality of life, transforming the urban area into an increasingly unhealthy place (MARIA; BIONDI; BOBROWSKI, 2016).

Thus, it is necessary to use technical measures that allow the public power to manage the urban environment in a sustainable way, among these measures there is the use of urban afforestation as a mitigating tool, due to the innumerable benefits offered by trees.

However, it is common for those responsible for urban forest planning and / or management to not have the necessary information atamarabout the existing patrimony, and the inventory is the most efficient and safe way

FLORESTA, Curitiba, PR, v. 49, n. 2, p. 267-276, abr/jun 2019. 
to obtain this information (SILVA; PAIVA; GONÇALVES, 2007). In this sense, Pires et al. (2010) state that the knowledge of the characteristics of urban environment is a precondition for the success of the afforestation, being important the knowledge of the species that compose the vegetation inside the city and in the surroundings, allowing the adequate selection of species recommended for the afforestation.

The inclusion of afforestation as part of the urban components requires adequate planning for the particular characteristics of each municipality. Nagenda and Gopal (2010) argue that for a more effective management of street trees, it is essential to have, in addition to the inventory data, spatial distribution data, the species that make up each region of the city and to maintain a regular monitoring.

Through spatial indices it is possible to indicate, for example, if the municipality is very or not very wooded (index of trees per kilometer of sidewalks), how many trees per $100 \mathrm{~m}^{2}$ of sidewalk (tree density index), what percentage (index of tree cover) and also to define which species are more adapted (index of performance of the species) and how many trees are still necessary for the municipality to present full afforestation (index of full occupation) of the area of sidewalk shaded by the projection of canopies. However, diversity indexes can be used to analyze natural or altered ecosystems, with the intention of finding patterns that offer reliable estimates of biological diversity (MORENO, 2001).

In this way, the present study had the objective of evaluating the spatial and biological diversity indexes of the street arborization of the city of Itanhaém, São Paulo, Brazil.

\section{MATERIAL AND METHODS}

The present study was developed in the municipality of Itanhaém, located on the south coast of the State of São Paulo (Figure 1), with zero mark under the coordinates $24^{\circ} 11$ "1 'South and 46 $47^{\prime \prime} 22^{\prime}$ West. The municipality has a territorial extension of $601.67 \mathrm{~km}^{2}$ with an urbanized area of $421.56 \mathrm{~km}$ of urbanized roads.

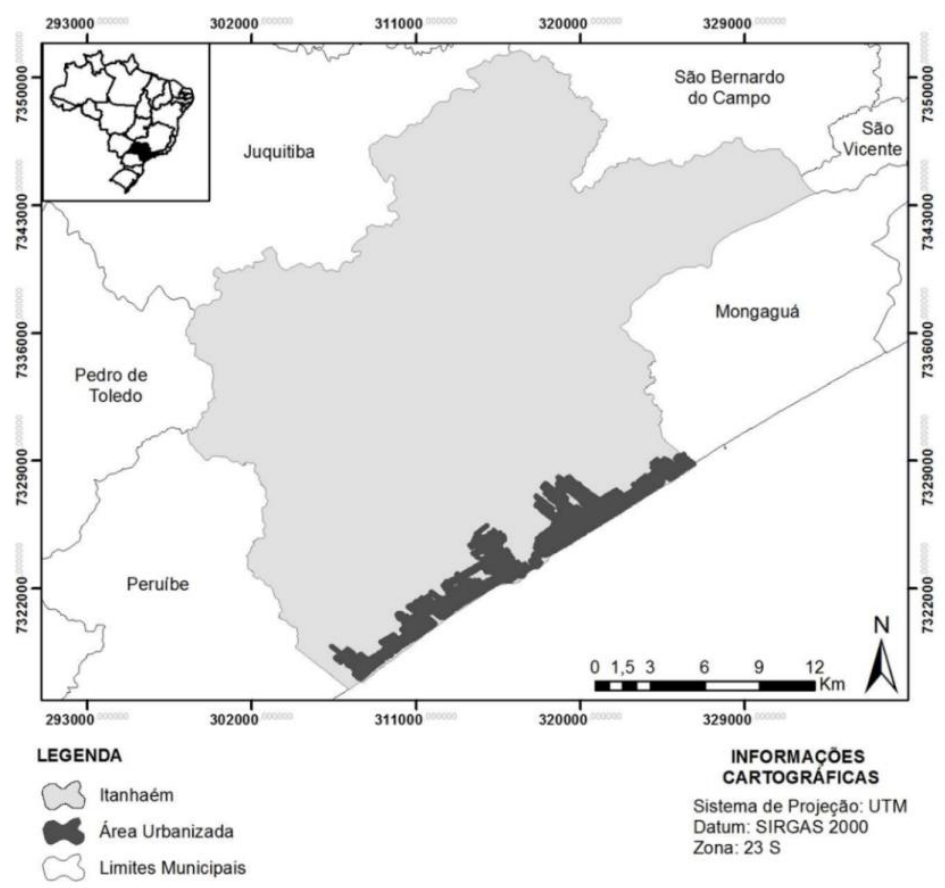

Figure 1. Location of the municipality of Itanhaém-SP.

Figura 1. Localização do município de Itanhaém-SP.

The predominant climate in the municipality is Af, according to the Köppen classification, characterized as a tropical climate without a dry season, with a monthly average rainfall of over $60 \mathrm{~mm}$ and the average temperature of the coldest month of $18^{\circ} \mathrm{C}$ (ALVAREZ, 2014).

The municipality has 97,000 inhabitants, with concentration of $99 \%$ of the population in the urbanized area, divided into 15 regional. However, for the evaluation of the afforestation, 13 regionals were considered, due to the lack of trees on sidewalks in the Guapura and Oasis regions.

For the knowledge and quantification of urbanized roads, the entire municipality was car-driven, identifying the urbanized roads for allocation in the Google Earth ${ }^{\circledR}$ software and subsequent determination of the 
kilometrage of urbanized roads of each region. All individuals of tree size (greater than $1.5 \mathrm{~m}$ ) were counted in the urbanized roads in order to characterize the spatialization of the trees.

For a qualitative knowledge of the afforestation and the physical space, an inventory was carried out by stratified sampling, having the administrative division of the municipality into 15 regional ones for the definition of strata. The shape of the sampling unit was linear, with a length of 100 meters.

The variables to be analyzed in the qualitative inventory were adapted from the methodology proposed by Milano (1984), where the parameters were evaluated: tree species and location, pavement tree position, pavement width, tree height, crown rays and physical and phytosanitary condition of trees, and served as a basis for calculating spatial indices.

For the location of the tree was evaluated the street, the neighborhood and the side (odd or even) where it is located, as well as the position of the tree on the sidewalk, through the distance of the curb, the construction and the next tree .

The height of the tree was measured using the hypsometer, as well as the height of the first bifurcation. The variables of circumference at chest height, crown rays and free area of the seedbed were measured using metric tape.

The physical conditions of the trees of the root system were evaluated on a qualitative scale, ranging from deep (1) to slightly superficial (2), and superficial (3). As for the structural and phytosanitary condition of the trees, the quantitative scale ranged from good (1), satisfactory (2), bad (3) and dead (4).

In order to determine the spatial indices of the Itanhaém-SP road, it was used the tree cover index (TCI) and tree density index (TDI) based on Lima Neto and Souza (2009); and the index of trees per kilometer of pavements (TIKP), full occupancy index (FOI), current occupancy rate (COR) and afforestation deficit, based on Silva, Paiva and Gonçalves (2007). In addition, some indices were adjusted, such as: adjusted full occupancy index (IFOIa), adjusted current occupancy rate (CORa), and adjusted afforestation deficit, with the respective equations set out in Table 1.

Table 1. Spatial indexes used to evaluate road arborization.

Tabela 1. Índices espaciais utilizados para avaliação da arborização viária.

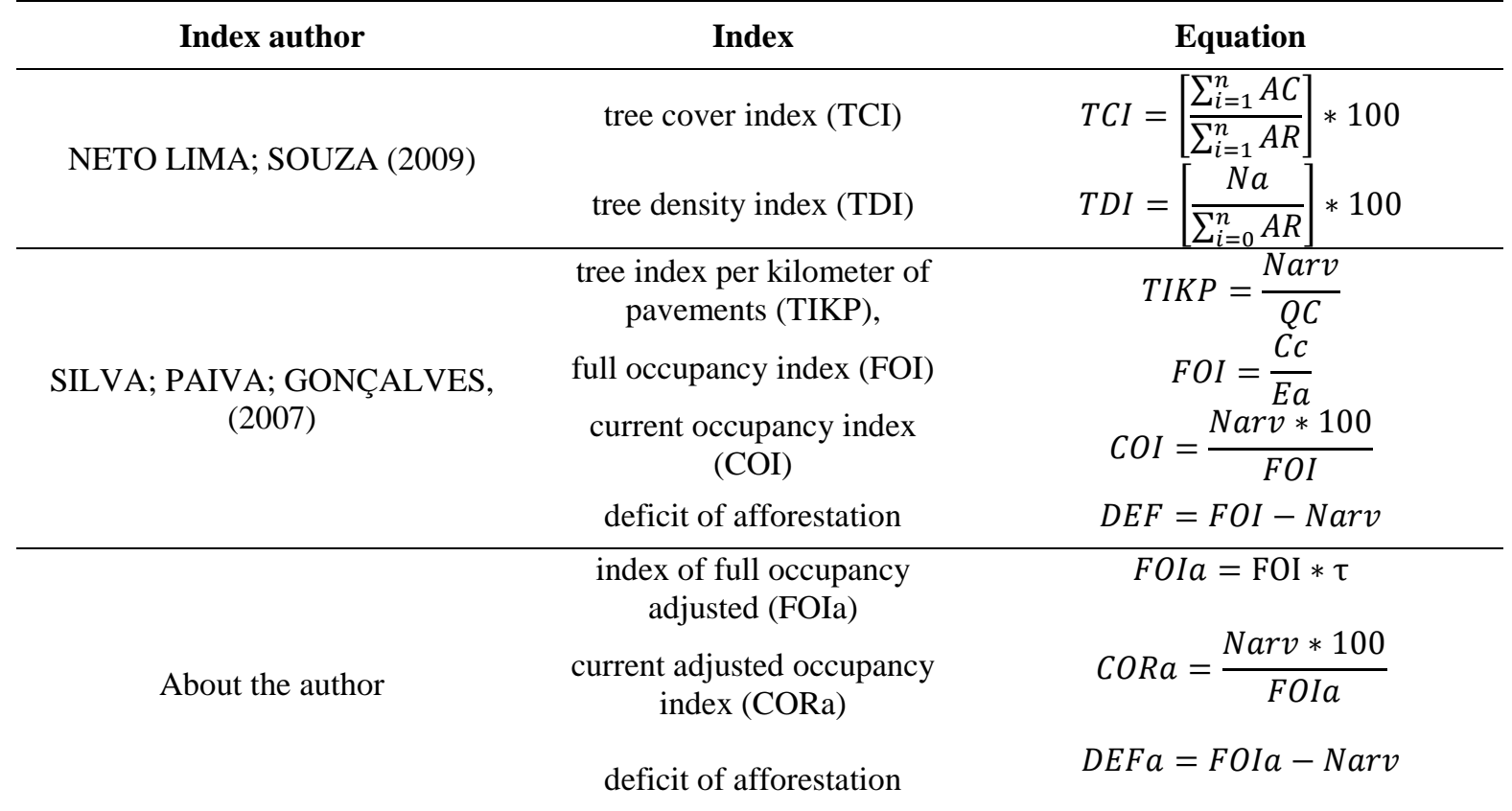

Subtitle: $\mathrm{n}$, number of streets sampled; CA, crown area of trees $\left(\mathrm{m}^{2}\right)$; SA = sidewalk area $\left(\mathrm{m}^{2}\right)$; Na, number of sample trees; Narv, number of trees; KS, kilometers of sidewalks (km); Cc, curb length (m); St, spacing between trees $(\mathrm{m})$; $\tau$ = coefficient of adjustment.

The index of full occupation (FOI) indicates the ideal number of individuals to be found, considering the full afforestation of the sidewalks (SILVA; PAIVA; GONÇALVES, 2007). However, the FOI does not take into account the conflicts of the afforestation with the urban furniture, ignoring the recommended minimum distances between the tree and the furniture.

Thus, in order to adjust the calculation methodology of the FOI, in order to consider the minimum distances between planting of trees and urban furniture, the adjusted FOI (FOIa) was formulated, respecting the 
minimum distances between tree and furniture (Table 2), prepared by the Secretariat of Green and Environment of São Paulo (2015).

Table 2. Minimum distances between afforestation planting and urban furniture Tabela 2. Distâncias mínimas entre o plantio da arborização e o mobiliário urbano.

\begin{tabular}{lrrrr}
\hline Carriage of the tree & Corner $(\mathbf{m})$ & Posts $(\mathbf{m})$ & Lowered Guide (m) & Tree species (m) \\
\hline Small Carriage & 5,00 & 2,00 & 1,00 & 5,00 \\
Medium Carriage & 5,00 & 3,00 & 1,00 & 8,00 \\
Large Carriage & 5,00 & 3,00 & 2,00 & 12,00 \\
\hline
\end{tabular}

The coefficient of adjustment $(\tau)$ was calculated according to the urban characteristics of each region, presenting a value related to the space occupied by urban furniture every $100 \mathrm{~m}$ of sidewalk, with an estimated $10 \%$ overlap of urban furniture removal measures (Figure 2).

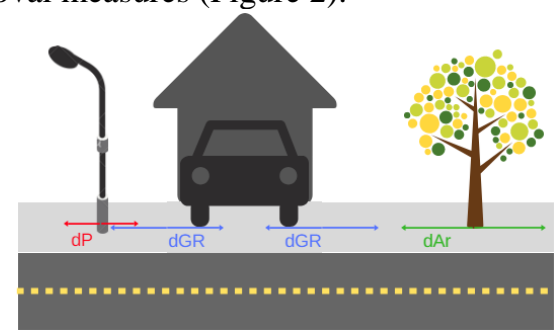

Figure 2. Example of overlapping the minimum distances of tree to the recessed guide (dGR) and post (dP). Figura 2. Exemplo de sobreposição das distâncias mínimas da árvore à guia rebaixada (dGR) e ao poste (dP)

The urban elements commonly found in the municipality: recessed guides, corners and poles, were considered for the calculation of the adjustment coefficient $(\tau)$ set forth in Table 3 .

Table 3. Parameters used to determine the calculation of the coefficient of adjustment $(\tau)$.

Tabela 3. Parâmetros utilizados para determinação do cálculo do coeficiente de ajuste $(\tau)$.

\begin{tabular}{|c|c|c|c|c|c|c|c|c|c|c|c|c|}
\hline \multirow{5}{*}{ 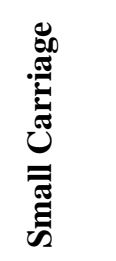 } & \multirow{2}{*}{$\begin{array}{c}\text { CP } \\
(\text { Hab / } \\
100 m) \\
\end{array}$} & \multicolumn{3}{|c|}{ Corner (m) } & \multicolumn{3}{|c|}{ Posts (m) } & \multicolumn{3}{|c|}{ Lowered Guide (GR) } & \multirow{2}{*}{$\begin{array}{l}\Sigma \mathbf{d t} \\
(\mathbf{m})\end{array}$} & \multirow[t]{2}{*}{$\tau$} \\
\hline & & tq & ud & Td & tq & ud & Td & tq & ud & Td & & \\
\hline & $0-10$ & 2 & 5 & 10 & 3 & 4 & 12 & 4 & 5 & 20 & 42 & $0-34$ \\
\hline & $10-20$ & 2 & 5 & 10 & 4 & 4 & 16 & 7 & 5 & 35 & 61 & $0-49$ \\
\hline & $>20$ & 2 & 5 & 10 & 5 & 4 & 20 & 10 & 5 & 50 & 80 & 0,63 \\
\hline \multirow{5}{*}{ 葛 } & CP (Hab / & \multicolumn{3}{|c|}{ Corner (m) } & \multicolumn{3}{|c|}{ Posts (m) } & \multicolumn{3}{|c|}{ Lowered Guide (GR) } & \multirow{2}{*}{$\begin{array}{l}\Sigma \mathbf{d t} \\
(\mathbf{m})\end{array}$} & \multirow[t]{2}{*}{$\tau$} \\
\hline & 100m) & tq & ud & Td & tq & ud & Td & tq & ud & Td & & \\
\hline & $0-10$ & 2 & 5 & 10 & 3 & 6 & 18 & 4 & 5 & 20 & 48 & 0,40 \\
\hline & $10-20$ & 2 & 5 & 10 & 4 & 6 & 24 & 7 & 5 & 35 & 69 & 0,56 \\
\hline & $>20$ & 2 & 5 & 10 & 5 & 6 & 30 & 10 & 5 & 50 & 90 & 0,72 \\
\hline \multirow{5}{*}{ 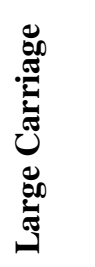 } & $\mathbf{C P}$ & \multicolumn{3}{|c|}{ Corner (m) } & \multicolumn{3}{|c|}{ Posts (m) } & \multicolumn{3}{|c|}{ Lowered Guide (GR) } & \multirow{2}{*}{$\begin{array}{l}\Sigma \mathbf{d t} \\
(\mathrm{m})\end{array}$} & \multirow[t]{2}{*}{$\tau$} \\
\hline & $\begin{array}{l}\text { (Hab / } \\
\text { 100m) }\end{array}$ & tq & ud & Td & tq & ud & Td & tq & ud & Td & & \\
\hline & $0-10$ & 2 & 5 & 10 & 3 & 6 & 18 & 4 & 7 & 28 & 56 & 0,47 \\
\hline & $10-20$ & 2 & 5 & 10 & 4 & 6 & 24 & 7 & 7 & 49 & 83 & 0,68 \\
\hline & $>20$ & 2 & 5 & 10 & 5 & 6 & 30 & 10 & 7 & 70 & 110 & 0,90 \\
\hline
\end{tabular}

Caption: Pc, population class; qt, quantity; ud, unit distance apart; td, total distance.

Thus, the adjustment coefficient $(\tau)$ ), was obtained by the folowwing equation:

in which $\tau=$ adjustment coefficient and $\mathrm{Td}=$ total distance

$$
\tau=1-\left(\sum \mathbf{d t} * \frac{0,9}{100}\right)
$$


It was considered, in order to quantify the number of posts, the population class, in which the number of poles was calculated by the poles allocation rules described in ND10 (ELEKTRO, 2017), which determines that the maximum distance of $30 \mathrm{~m}$ between poles and the policy of 2 houses per posts must be respected.

For the quantification of the number of recessed guides, approximately one recessed guide was considered for each three inhabitants, where it was considered the width of $2.0 \mathrm{~m}$ of span for each recessed guide, and twice the distancing of the furniture described by SVMASP (2015):

$$
d t G R=[2+(2 * d u)] * \mathrm{qt}
$$

where: $\operatorname{tdRG}=$ total distance of the recessed Guide, $\mathrm{udRG}=$ unitary repulsion distance of the retracted guide (sorted by size); qt = total quantity of lowered guides.

Regardless of the size of the afforestation and the population class (PC), two corners were considered at each $100.0 \mathrm{~m}$ of sidewalk.

The ecological indexes were used to determine the biological diversity of the trees, the richness, the equity, the dominance and the performance index of the species.

The diversity of species among the regional ones was determined by the Shannon index $\left(H^{\prime}\right)$, the dominance by the Simpson index $(\boldsymbol{\lambda})$, the wealth by the Margalef index (Dmg) and the equity measured by Pielou $\left(\mathrm{J}^{\prime}\right)$. According to Moreno (2001) and Magurran (2011), such indices are described by the equations shown in Table 4.

Table 4: Ecological indices used and their respective equations.

Tabela 4. Índices ecológicos utilizados e respectivas equações.

\begin{tabular}{ccc}
\hline Index Class & Index name & Equation \\
\hline Diversity & Shannon & $H^{\prime}=-\sum p_{i}\left(\ln p_{i}\right)$ \\
Dominance & Simpson & $\lambda=\sum p_{i}^{2}$ \\
Species richness & Margalef & $D m g=\frac{S-1}{\ln N}$ \\
Equity & Pielou & $J^{\prime}=\frac{H^{\prime}}{H^{\prime}{ }_{\text {max }}}$ \\
\hline
\end{tabular}

Caption: $\mathrm{S}=$ Total number of species sampled, $\mathrm{N}=$ Total number of individuals sampled, $p$ i= Proportion of individuals of the same species in the total sampled, $\mathrm{H}^{\prime}{ }_{\max }=\ln (\mathrm{S})$.

Stranghetti and Silva (2010) state that the knowledge of the vegetation diversity is of paramount importance for the maintenance, fixation and extension of the ecological balance of afforestation in the urban environment.

To evaluate the development of the species, the performance index of the species was calculated based on the adaptation of Bobrowski, Ferreira and Biondi (2016), to indicate which species are best adapted to the environment in which they are inserted, considering species well adapted, those with IPE greater than one where:

$$
I P E=\frac{n a B+n a S}{\left(\frac{N a B+N a S}{N}\right)} * 100
$$

SPI = Species Performance Index, $\mathrm{ntB}=$ Number of trees of species "e" that are in condition class "Good", ntS = Number of trees of species "e" in condition class "Satisfactory", NaB = Total number of trees sampled in Good condition, $\mathrm{NaS}=$ Total number of trees sampled in Satisfactory condition, $\mathrm{N}=$ Total number of trees sampled at work.

The IPE was calculated only for the species that presented representation of at least 10 adult individuals (with a height superior to 1,5 meters) in the arborization of the municipality.

\section{RESULTS}

\section{Spatial indexes}

The results showed a large variance of the arborization between regional ones, where the index of trees per kilometer of pavements (TIKP) ranged from 7 to 45 tree $/ \mathrm{km}$ of sidewalk, averaging for the municipality 21 tree/ km of sidewalk (Table 3). 
Table 3. Spatial and ecological indexes of the road tree growing in Itanhaém-SP.

Tabela 3. Índices espaciais e ecológicos da arborização viária de Itanhaém-SP.

\begin{tabular}{|c|c|c|c|c|c|c|c|c|c|c|c|c|c|c|c|c|c|c|}
\hline \multirow{2}{*}{ Regional } & \multicolumn{5}{|c|}{ Gross data } & \multicolumn{9}{|c|}{ Spatial indices } & \multicolumn{4}{|c|}{ Ecological indices } \\
\hline & Narv & NE & NI & $\mathbf{A R}$ & $\mathbf{A C}$ & ICA & IDA & TIKP & FOI & COR & Def & FOIa & CORa & Defa & $H^{\prime}$ & Dmg & $J^{\prime}$ & $\lambda$ \\
\hline $\begin{array}{l}\text { Belas Artes e } \\
\text { Corumbá }\end{array}$ & 912 & 31 & 85 & 89697 & 1010 & 1,13 & 1,02 & 14 & 12800 & 7,1 & 11888 & 6579 & 13,9 & 5667 & 2,87 & 6,75 & 0,83 & 0,11 \\
\hline Bopiranga & 1963 & 21 & 63 & 89009 & 1138 & 1,28 & 2,21 & 35 & 7098 & 27,7 & 5135 & 3691 & 53,2 & 1728 & 2,66 & 4,83 & 0,87 & 0,11 \\
\hline Centro & 1011 & 31 & 137 & 68912 & 4472 & 6,49 & 1,47 & 22 & 9296 & 10,9 & 8285 & 6117 & 16,5 & 5106 & 2,98 & 6,10 & 0,87 & 0,08 \\
\hline Cibratel & 3914 & 30 & 171 & 235462 & 4883 & 2,07 & 1,66 & 25 & 19410 & 20,2 & 15496 & 10093 & 38,8 & 6179 & 2,54 & 5,64 & 0,75 & 0,16 \\
\hline Gaivota & 2366 & 22 & 125 & 146787 & 1993 & 1,36 & 1,61 & 24 & 19772 & 12,0 & 17406 & 13010 & 18,2 & 10644 & 2,68 & 4,35 & 0,85 & 0,00 \\
\hline $\begin{array}{l}\text { Guapiranga e } \\
\text { Sabaúna }\end{array}$ & 237 & 19 & 45 & 43072 & 1248 & 2,90 & 0,55 & 7 & 6368 & 3,7 & 6131 & 2356 & 10,1 & 2119 & 2,74 & 4,73 & 0,93 & 0,08 \\
\hline Ivoty & 456 & 24 & 65 & 57747 & 1506 & 2,61 & 0,79 & 11 & 8088 & 5,6 & 7632 & 4157 & 11,0 & 3701 & 2,59 & 5,51 & 0,81 & 0,13 \\
\hline Loty & 2473 & 30 & 180 & 95194 & 3182 & 3,34 & 2,60 & 45 & 6875 & 36,0 & 4402 & 3575 & 69,2 & 1102 & 2,76 & 5,58 & 0,81 & 0,07 \\
\hline Mosteiro & 90 & 9 & 35 & 15219 & 880 & 5,79 & 0,59 & 8 & 2316 & 3,9 & 2226 & 1524 & 5,9 & 1434 & 2,30 & 2,25 & 1,05 & 0,13 \\
\hline $\begin{array}{l}\text { Praia Dos } \\
\text { Sonhos }\end{array}$ & 303 & 19 & 74 & 23489 & 1802 & 7,68 & 1,29 & 13 & 4756 & 6,4 & 4453 & 3129 & 9,7 & 2826 & 2,94 & 4,18 & 1,00 & 0,00 \\
\hline $\begin{array}{l}\text { Savoy e Nova } \\
\text { Itanhaém }\end{array}$ & 1777 & 27 & 96 & 219723 & 2254 & 1,03 & 0,81 & 11 & 32684 & 5,4 & 30907 & 21506 & 8,3 & 19729 & 2,94 & 5,70 & 0,89 & 0,07 \\
\hline Suarão & 2018 & 34 & 166 & 83766 & 3693 & 4,41 & 2,41 & 29 & 13900 & 14,5 & 11882 & 9146 & 22,1 & 7128 & 2,92 & 6,45 & 0,83 & 0,09 \\
\hline Umuarama & 443 & 13 & 23 & 23567 & 380 & 1,61 & 1,88 & 34 & 1620 & 27,3 & 1177 & 454 & 97,7 & 11 & 2,48 & 3,8 & 0,97 & 0,10 \\
\hline $\begin{array}{l}\text { In the } \\
\text { municipality }\end{array}$ & 18128 & 109 & 1265 & 1208570 & 28446 & 2.35 & 1,5 & 21 & 147623 & 12,3 & $\begin{array}{r}12949 \\
5\end{array}$ & 85865 & 21,1 & 67737 & 3,35 & 15.12 & 0.71 & 0.08 \\
\hline
\end{tabular}

Caption: Narv, number of trees; AR, sidewalk area $\left(\mathrm{m}^{2}\right)$; AC, cup area $\left(\mathrm{m}^{2}\right)$; TCI, tree cover index (\%); TDI, tree density index (arv / 100sqm); TIKP, index of trees per kilometer of sidewalk (arv / kmc); FOI, index of Caption: Narv, number of trees; AR, sidewalk area $\left(\mathrm{m}^{2}\right)$; AC, cup area $\left(\mathrm{m}^{2}\right)$; TCI, tree cover index (\%); TDI, tree density index (arv / 100sqm); TIKP, index of trees per kilometer of sidewalk (arv / kmc); FOI, index of
full occupation;COR, current occupancy rate (\%); DEF, afforestation deficit; FOIa, adjusted full occupancy index; CORa, adjusted current occupancy index (\%); DEFa, adjusted afforestation deficit; H ', Shannon diversity index; Dmg, Margalef specific wealth index; J ', Pielou equity index; $\lambda$, Simpson dominance index

$\begin{array}{rr}272 & \text { FLORESTA, Curitiba, PR, v. 49, n. 2, p. 267-276, abr/jun } 2019 \\ \text { Maria. T. R. B. C. et.al. } \\ \text { Electronic ISSN 1982-4688 } \\ \text { DOI: } 10.5380 / \text { rf.v49 i2.57451 }\end{array}$




\section{Performance Index of the species}

The performance index was calculated for 19 species, between exotic and native. The species that presented the highest Performance Index (Table 4) should be considered in the new plantations (except exotic and invasive species).

Table 4. Index ranking of tree species performances in the Itanhaém-SP road afforestation

Tabela 4. Ranking do Índice de performances das espécies arbóreas na arborização viária de Itanhaém-SP.

\begin{tabular}{cccc}
\hline Position & Scientific name & IPE & FR (\%) \\
\hline $1^{\circ}$ & Tecoma stans (L.) Juss. Ex HBK & 1,25944 & 0,28 \\
$2^{\circ}$ & Schinus terebinthifolius Raddi & 1,25944 & 1,68 \\
$3^{\circ}$ & Schefflera arboreal (Hayata) Merr. & 1,25944 & 1,54 \\
$4^{\circ}$ & Handroanthus chrysotrichus (Mart. Ex DC.) Mattos & 1,20219 & 2,23 \\
$5^{\circ}$ & Psidium guajava L. & Perimeter & 0,28 \\
$6^{\circ}$ & Handroanthus sp. Mattos & 1,17548 & 1,26 \\
$7^{\circ}$ & Lagerstroemia indicates (L.) Pers. & 1,17548 & 1,68 \\
$8^{\circ}$ & Murraya paniculata L. Jack & 1,09152 & 1,54 \\
$9^{\circ}$ & Licania tomentosa (Benth.) Fritsch & 1,04954 & 1,40 \\
$10^{\circ}$ & Eugenia uniflora L. & 1,03719 & 2,09 \\
$11^{\circ}$ & Cassia fistula L. & 0,94458 & 2,09 \\
$12^{\circ}$ & Delonix regia (Bojer ex Hook.) Raf. & 0,93089 & 2,65 \\
$13^{\circ}$ & Spathodea campanulata P. Beauv. & 0,92359 & 1,68 \\
$14^{\circ}$ & Nerium oleander L. & 0,88627 & 2,93 \\
$15^{\circ}$ & Terminalia catappa L. & 0,86052 & 10,34 \\
$16^{\circ}$ & Hibiscus rosa-sinensis L. & 0,83963 & 1,82 \\
$17^{\circ}$ & Morus nigra L. & 0,77504 & 1,54 \\
$18^{\circ}$ & Ficus benjamina L. & 0,70695 & 13,27 \\
$19^{\circ}$ & Cassia bicapsularis & 0,62972 & 1,26 \\
\hline
\end{tabular}

Caption: IPE, performance index; FR, frequency (\%)

\section{DISCUSSION}

\section{Spatial indices}

The variation of 7 to 45 arv / $\mathrm{km}$ between the regional ones is likely to be associated with the different urbanization characteristics of the neighborhoods, such as the average width of the sidewalk and the proximity of forest remnants in the urban area and the age of allotments.

Paiva et al. (2010) considers ideal when the index is 100 trees per kilometer, considering the occurrence of at least one tree in front of each residence, estimating a tested urban average of $10.0 \mathrm{~m}$. When considering the affirmative of Paiva et al. (2010), it can be seen that in the region "Guapiranga e Sabaúna", in every 100 houses, 7 of them have trees on their sidewalks, while for the regional "Loty", 45 houses present at least one tree in front of their residence, which shows the enormous deficit of afforestation in all municipality.

The Arborea Coverage Index of the sidewalks (TCI) showed that the regional "Praia dos Sonhos" was the one that obtained greater tree cover with $7.67 \%$ of its sidewalks shaded by the area of canopy of the trees, whereas the regional "Savoy e Nova Itanhaém" presented the lowest ICA with $1.03 \%$ of sidewalks with tree cover.

Concerning the index of full occupation (FOI), it was possible to observe the need to plant 147,623 trees in the urban area, disregarding the urban interferences. However, FOIa, which considers street furniture, demonstrated the need to install 85,865 trees, indicating a reduction of about $58 \%$ between the pure index and the adjusted index.

The largest difference between the FOI and FOIa was for regional "Umuarama", which considered the need to deploy 1,620 trees for the pure index and 454 trees for the adjusted index. This reduction of $72 \%$ in the number of trees to be implanted occurred, since this is the regional with the greatest number of inhabitants for each $100 \mathrm{~m}$, demonstrating a greater need of urban infrastructure, reducing the spaces available for afforestation.

In both FOI and DEF, as in FOIa and DEFa, the regional "Savoy e Nova Itanhaém" presented the highest values, with FOI of 32,684 trees and FOIa of 21,506 trees, and DEF of 30,907 trees and DEFa of 19,729 trees. The values were higher in this region, since it is the one that presented the highest linear kilometrage of sidewalks and is in the lowest class of inhabitants per $100 \mathrm{~m}$, demonstrating a greater spacing between urban furniture and greater availability of space for the implantation of afforestation.

FLORESTA, Curitiba, PR, v. 49, n. 2, p. 267-276, abr/jun 2019. 
The lowest difference between the FOI, DEF and COR indices and the FOIa, DEFa and CORa indices occurred in the regional "Mosteiro", with a difference of 792 trees between FOI and FOIa, and a difference of 2\% between COR and CORa. The smallest difference between the FOI and the FOIa was due to the fact that this was the regional with least stretch of sidewalks $(11.58 \mathrm{~km})$. The smallest difference between the COR and the CORa was the regional one with the fewest trees (90), showing little interference with the current occupation.

\section{Ecological indices}

The diversity described by the Shannon index in the municipality of Itanhaém-SP is superior to that found in Assis-SP with H'= 2,91 (ROSSATTO, TSUBOY, FREI, 2008) and the one in Ribeirão Preto-SP with H' = 3, 14 (ROMANI et al., 2012).

The value found for the Shannon diversity index considers the municipality with high species diversity, since for Scolforo, Mello and Silva (2008) the higher the value of $\mathrm{H}^{\prime}$, the greater the floristic diversity of the studied area.

The knowledge of the diversity of species that occurs in the afforestation of streets allows a more efficient management of the strategies for the plantations (SREETHERAN et al ., 2011). In this sense, the regional one that showed less diversity by the Shannon index was the "Mosteiro" $\left(\mathrm{H}^{\prime}=2,3\right)$, demonstrating that there is a need to implement new species in order to increase diversity.

It can be affirmed that even so the road arborization of Itanhaém-SP presents one high index of diversity of Shannon, the values can be potentialized with the use of new found native species in Atlantic Mata, since that carried through an adjusted planning, evaluating the development to the field of the species to be inserted.

Simpson's dominance index was higher in the regional "Cibratel" with $=0.165$, which indicates that the possibility of two randomly selected individuals being of the same species is greater than $16 \%$, this low probability indicates that still then, regional presents a very diverse afforestation.

Simpson's dominance found for the municipality was 0.08 , which shows that there is no dominance of species in Itanhaém, i. e., the probability of two individuals randomly selected among the entire municipal extension being of the same species is low (8\%).

The low index of dominance is confirmed when compared to other areas of study, such as the one found in the urban arborization of Goiandira-GO with a value of 0.14 (Pires et al., 2010).

The wealth of Margalef found for Itanhaém was 15.12, representing a great biodiversity. The value found in Itanhaém was higher than the urban forest fragments of Porto Alegre, with an index ranging from 4.62189 to 7.64656 (TORRES; TODESCHINI; FARIA, 2018); however, it is still lower than the value of 26 found by Richter et al. al. (2012) in the city of Mata-RS.

No regional presented values of low biodiversity according to the Margalef index, of the 13 regional evaluated, 7 presented values of Margalef above 5.0, such as: "Belas Artes e Corumbá", "Centro", "Cibratel", "Ivoty", "Loty", "Savoy e Nova Itanhaém" and "Suarão".

The Pielou (E) equitability index was 0.71 , which demonstrates a greater species uniformity in the afforestation of the municipality. The regional "Mosteiro" was the one that presented the highest value for fairness of Pielou 1,04, demonstrating a high uniformity regarding the species present in the arborization of this region. This result is corroborated by this being the region with the lowest number of species in the afforestation (9).

The result found in the municipality for the Pielou index (E) was superior to that found in Lages-SC with $\mathrm{E}=0.49$ (SANTOS, et al. 2013); and similar to that found in Mata-RS with $\mathrm{E}=0.7$ (RICHTER et al., 2012).

\section{Performance Index of the species}

The species that showed the best development in the municipality according to PIE were $T$. stans, $S$. terebinthifolius and $S$. arborea, but it should be emphasized that the $T$. stans is a species of exotic origin and invasive species, as well as species P. guajava (INSTITUTO HORUS, 2016), and therefore should not be considered for new plantations, even with good adaptation to the municipality.

Among the species with the highest PIE in the municipality are H. chrysotrichus and L. indica, commonly used in the afforestation of streets (STRANGHETTI; SILVA, 2010; PIRES et al., 2010; SANTOS et al., 2012; SULEVIS BIONDI, 2014; BOBROWSKI; FERREIRA; BIONDI, 2016). Positive values of PIE for the species $H$. chrysotrichus (1.07) were also found in the Curitiba road arborization, demonstrating that the natural conditions of the species makes it easily adaptable to the urban environment (BOBROWSKI; FERREIRA; BIONDI, 2016).

From the results, it can be observed that the tree species more frequent in the composition of the road arborization of the city (T. catappa and F. benjamina) presented low values of PIE (below of 1,0 ), demonstrating that the majority of the individuals of both the species are not well adapted to the urban way or are very deprived of characteristics due to the pruning. 
For the species with low frequency and bigger values of PIE, it is recommended and accomplishment of experimental plantings with native species not yet implanted (or with few units in the arborization of the city) so that it can be analyzed the PIE of them, aiming at the indication and production of changes of adequate species to the city.

\section{CONCLUSIONS}

- The results of the spatial indexes showed a shortage of individuals in the municipal road afforestation, with an adjusted deficit of 67,737 trees, indicating a need to intensify the seedlings and changes-producing programs so that, in a planned way, the ideal value of the tree cover of the municipality.

- The ecological indexes showed high species diversity in the city's forested area. The equity of Pielou has shown that equality in the abundance of species among the regional is greater than that found for the municipality. The Simpson dominance index showed that there is no species dominance in any of the regional or municipalities.

- The performance index of the species showed that the species with the highest frequency of the municipality ( $T$. catappa and $F$. benjamina) presented low adaptability, being recommended the suspension of the planting of individuals of these species.

\section{REFERENCES}

ALVARES, CA; STAPE, JL; SENTELHAS, PC; GONÇALVES, JLM; SPAROVEK, G. Köppen's climate classification map for Brazil. Meteorologische Zeitschrift, Stuttgart, v. 22, n. 6, p. 711-728, 2014.

BOBROWSKI, R .; FERREIRA, RLC; BIONDI, D. Phytosociological description of the afforestation of streets through different forms of expression of dominance and density. Forest Science, Santa Maria, v. 26, n. 4, p. 1167 1178, Oct.-Dec., 2016.

ELEKTRO ND.10 Supply of Electricity in Secondary Voltage to Individual Buildings. Campinas, 2017.

INSTITUTE HÓRUS OF DEVELOPMENT AND ENVIRONMENTAL CONSERVATION. National Database of Invasive exotic Species I3N Brazil. 2016 Available in: . Accessed on: 22 Oct. 2016

LIMA NETO, EM; SOUZA, RM Index of Shading and Tree Density of the public green areas of Aracaju-SE. Journal of the Brazilian Society of Urban Arborization, Piracicaba, v. 4, n. 4, p. 47-62, 2009.

MAGURRAN, AE Measuring biological diversity. Curitiba: Publisher of UFPR, 2011.

MARIA, TRBC; BIONDI, D .; BOBROWSKI, R. Qualitative quantitative floristic inventory of the pubic pathways of Itanhaém - SP. Journal of the Brazilian Society of Urban Arborization, Piracicaba, v. 11, n. 4, p. 79-97, 2009.

MILANO, M S. Evaluation and Analysis of Arborization of Streets of Curitiba-PR. 130f. Dissertation (Master in Forest Sciences), UFPR, Curitiba, Paraná, 1984.

MORENO, EC Methods for measuring biodiversity. Zaragoza. M \& T Manuals and Thesis, 2001. 84p.

NAGENDRA, H .; GOPAL, D. Street trees in Bangalore: Density, diversity, composition and distribution. Urban forestry and urban greening, Amsterdam, v.9, p. 129-137, 2010.

PAIVA, AV; LIMA, ABM; CARVALHO, A .; JUNIOR, A .; GOMES, A .; MELO, CS; FARIAS, CO; REIS, C ; BEZERRA, C ; JUNIOR, EAS; MACEDO, E .; LIMA, ES; NEPHEW, F .; SILVA, FM; BONFIM, JC; JUNIOR, LS; CORREA, M .; DUMONT, ML; JUNIOR, MAI; PANTOJA, NV; DAVILA, RM; GABRIEL, R .; SILVA, RA; CUNHA, RM; OLIVEIRA, RS; DIAS R .; NICHELI, SP; COSTA, S .; SOUZA, TC; PEREIRA, TF; CASTELO, Z .; FERRARI, ZS Inventory and diagnosis of the urban arborization of Rio Branco, AC. Journal of the Brazilian Society of Urban Arborization, Piracicaba, v. 5, n. 1, p. 144-159, 2010.

PIRES, NAMT; MELO, MS; OLIVEIRA, DE; XAVIER-SANTOS, SA Urban forestry in the city of Goiandira / GO - qualitative and quantitative characterization and management proposals. Journal of the Brazilian Society of Urban Arborization, Piracicaba, v. 5, n. 3, p. 185-205, 2010.

RICHTER, C .; REFERENCES ROBAINA, AD; SOUZA, ARC; FERRAZ, RC; DAVID, AF Survey of public urban afforestation in Mata / RS. Journal of the Brazilian Society of Urban Arborization , Piracicaba, v. 7, n. 3, p. 88-96, 2009.

FLORESTA, Curitiba, PR, v. 49, n. 2, p. 267-276, abr/jun 2019.

Maria. T. R. B. C. et.al.

ISSN eletrônico 1982-4688

DOI: $10.5380 /$ rf.v49 i2.57451 
ROMANI, GN; GIMENES, R .; SILVA, MT; PIVETTA, KFL; BATISTA, GS Qualitative and quantitative analysis of afforestation in November XV in Ribeirão Preto, SP, Brazil. Tree Magazine, Viçosa, v. 36, n.3, p. 479-487, 2012.

ROSSATTO, DR; TSUBOY, MSF; FREI, F. Urban planting in the city of Assis-SP: a quantitative approach. Journal of the Brazilian Society of Urban Arborization , Piracicaba, v. 3, n. 3, p. 1-16, 2008.

SANTOS, EM; SILVEIRA, BD; SOUZA, AC; SCHMITZ, V ; SILVA, AC; HIGUCHI, P. Quali-quantitative analysis of urban afforestation in Lages, SC. Journal of Agroveterinary Sciences, Lages, v.12, n.1, p.59-67, 2013.

SECRETARY OF GREEN AND ENVIRONMENT OF SÃO PAULO. Technical manual for urban afforestation. City Hall of São Paulo. São Paulo, 2015, 124p.

SCOLFORO, JR S; MELLO, JM de; SILVA, CP of C. Forest inventory of Minas Gerais: Semideciduous and Ombrophilous Seasonal Forest: floristics, structure, diversity, similarity, diametric and height distribution, volumetry, growth trends and areas suitable for forest management. Lavras UFLA, 2008. 816 p.

SILVA, AG; PAIVA, HN, GONÇALVES, W. Evaluating the urban afforestation. Viçosa: Editora Aprendiz Fácil, 2007. 346 p. (Urban Arborization Series - Gardening and Landscaping Collection, Vol. 5).

STRANGHETTI, V .; SILVA, ZAV Diagnosis of afforestation of the public roads of the municipality of Uchôa SP. Journal of the Brazilian Society of Urban Arborization, Piracicaba, v. 5, n. 3, p. 185-205, 2010.

SREETHERAN, M .; ADNAN, M .; KHAIRIL AZUAR, AK Street tree inventory and tree risk assessment of selected major roads in Kuala Lumpur, Malaysia. Arboriculture \& Urban Forestry, Champaign, v.37, n.5, p.226-235, 2011

SULEVIS, C .; BIONDI, D. Morphological analysis of tree-planting species from Curitiba-PR and infestation by birdgrass. Journal of the Brazilian Society of Urban Arborization, Piracicaba, v. 9, n. 2, p. 1-17, 2009.

SANTOS, EM; SILVEIRA, BD; SOUZA, AC; SCHMITZ, V ; SILVA, AC; HIGUCHI, P. Quali-quantitative analysis of urban afforestation in Lages, SC. Journal of Agroveterinary Sciences, Lages, v.12, n.1, p.59-67, 2013.

TORRES, VS; TODSCHINI, F .; FARIAS, MF Ecological evaluation of two urban areas with strong anthropogenic influence. UNISANTA Bioscience, Santos, v. 7, n. 1, p. 51-68, 2018 